\title{
Landelijk scholingsaanbod medisch onderwijs
}

De Stichting ODOS is opgeheven!

Voor niet-ingewijden: de Stichting voor Onderwijskundige en Didactische Ontwikkeling en Scholing (voor het gezondheidszorgonderwijs) werd in 1994, als een gezamenlijk initiatief door de Nederlandse Vereniging voor Medisch Onderwijs en het Disciplineoverlegorgaan Medische Wetenschappen (DMW) van de gezamenlijke decanen van de medische faculteiten, opgericht. Tot voor kort verzorgde de Stichting ODOS landelijke scholing onder de naam Specialisatie Medisch Onderwijs (SMO). Met een behoorlijke subsidie van DMW vanaf 1996 was het de bedoeling dat binnen enkele jaren een kostendekkend cursuspakket zou worden gerealiseerd. Dat is niet gelukt. De uitgaven waren steeds groter dan de inkomsten en het DMW trok de consequente conclusie: geen verdere subsidie meer voor een niet-haalbare zaak.

Wat is er toch aan de hand? Nieuwe ontwikkelingen in medische curricula nemen hand over hand toe, de roep om professionalisering van medische docenten wordt steeds vaker gehoord, de belangstelling bij docenten voor medischonderwijskundige ontwikkelingen neemt, gezien het groeiend bezoekersaantal van het NVMO-congres, nog jaarlijks toe en de pers van een aantal ODOS-cursussen is prima. ${ }^{1}$ Is het dan logisch dat we in deze tijd besluiten dat er minder scholing moet komen? Het lijkt erop dat bedrijfs- economische overwegingen botsen met de werkelijke behoefte aan scholing in het medisch onderwijs. De medische opleiding behoort tot de duurste studies. Honderden docenten zijn betrokken bij iedere medische opleiding. Zij zijn als docent vaak minder professioneel dan in de meeste andere universitaire opleidingen - velen zijn immers in de eerste plaats dokter. Dan kan toch gebrek aan geld noch behoefte de werkelijke reden zijn om landelijke scholing te staken.

Daar komt nog iets bij. In het onderwijs zijn we gewend ons in de eerste plaats te spiegelen aan het onderwijs dat we vroeger zelf hebben gehad of dat we van nabij hebben meegemaakt. Zien hoe anderen het elders doen en contact met collega's in andere faculteiten biedt eye-openers en relativeert de soms vastgeroeste gewoonten die men in het eigen onderwijs heeft. Landelijke cursussen kunnen, naast scholing in de faculteiten, een prima rol spelen in die uitwisseling van ervaringen. Daar worden we allemaal beter van.

Laat het NVMO-bestuur zich bezinnen op een oplossing!

Olle ten Cate

\section{Literatuur}

1. Hoekstra JH. SMO-cursus 'Co-assistentschappen: onderwijs in de klinische fase'. Tijdschrift voor Medisch Onderwijs 2001;20(1):40-1. 